1.01

\title{
Denis Cerkvenik*
}

\section{Nacistična rekrutacija in urjenje sovjetskih vojnih ujetnikov na primeru 162. turkestanske divizije (1942-43)}

\section{IZVLEČEK}

Članek bo na primeru pripadnikov 162. turkestanske divizije prikazal kako so nacisti rekrutirati prostovoljce med sovjetskimi vojnim ujetniki ter jih poskušali ideološko indoktrinirati in disciplinsko izuriti, da bi se čim uspešneje integrirali $v$ Wehrmacht. Kljub nacističnemu trudu, da bi se turkestanski prostovoljci kar se da dobro vključili v nemško vojsko, pa so med turkestanskim in nemškim moštvom vedno obstajala trenja, katera so se pokazala tudi ob prihodu divizije na območje Operacijske cone Jadransko Primorje.

Ključne besede: kolaboracionisti, druga svetovna vojna, Turkestan, Sovjetska zveza, rekrutacija, vojni ujetniki, nacizem, islam

\section{ABSTRACT}

\section{NAZI RECRUITMENT AND TRAINING OF SOVIET PRISONERS OF WAR ON THE EXAMPLE OF THE $162^{\text {ND }}$ TURKESTANI DIVISION (1942-43)}

The article focuses on the collaborationists of the $162^{\text {nd }}$ Turkestani Division as an example of how the Nazis recruited volunteers among the Soviet prisoners of war and attempted to ideologically indoctrinate and discipline them in order to integrate them into the Wehrmacht as successfully as possible. Despite the efforts to integrate Turkestani volunteers into the 
German army, tensions persisted between the Turkestani and German soldiers, which became evident when the $162^{\text {nd }}$ Turkestani Division arrived at the Operation Zone of the Adriatic Littoral.

Keywords: collaborationists, World War II, Turkestan, Soviet Union, recruitment, prisoners of war, Nazism, Islam

\section{Uvod}

Nacistična Nemčija si je z operacijo Barbarossa zadala nalogo uničiti Sovjetsko zvezo. Vendar so najprej v Wehrmachtu, ${ }^{1}$ potem pa še v Hitlerjevem krogu spoznali, da se zaradi številnih izgub ne bodo mogli zanašati samo na Nemce, temveč si bodo morali pomagati tudi s pripadniki različnih etnij Sovjetske zveze, ki bi se bili pripravljeni bojevati proti dominantnemu ruskemu narodu in boljševizmu. Med temi etnijami so Hitler in njegovi sodelavci najbolj cenili turkestanske ${ }^{2}$ in kozaške prostovoljce, ${ }^{3}$ enote nastale iz teh dveh etniji pa so pustile pomemben pečat na območju Operacijske cone Jadransko primorje (OZAK).

Članek se ukvarja s vprašanji rekrutiranja in urjenja pripadnikov 162. turkestanske divizije, ki se je na območju OZAK borila za naciste. Če je o kozakih, ki so se tudi bojevali na območju OZAK, že nastalo nekaj raziskav, ${ }^{4}$ se s 162 . turkestansko divizijo razen Paola Dossena še nihče ni obširneje ukvarjal. Pomanjkljivost njegove knjige, Hitler's Turkestani Soldiers: A History of the 162nd (Turkistan) Infantry Division, je, da se skoraj izključno opira na italijanske in angleške vire, poleg tega pa v knjigi namenja veliko več pozornosti misticizmu Hitlerjevega kroga in različnim italijanskim partizanskim frakcijam kot pa sami diviziji. Kratko predstavitev 162. turkestanske divizije je naredil Pier Arrigo Carnier, ${ }^{5}$ medtem ko je nacistično uporabo turkestanske divizije na območju

1 Samuel J. Newland, Cossacks in the German Army (Abingdon: Routledge, 2002), 146.

2 Območje Osrednje Azije, ki vključuje Kazahstan, Uzbekistan, Tadžikistan, Turkmenistan, Kirgizistan in del vzhodne Kitajske se imenuje Turkestan. Znotraj Turkestana je Turkmenistan, država s podobnim imenom. Nemški dokumenti o legionarjih in prostovoljcih skoraj vedno govorijo izključno o Turkestanih. Tudi ko se govori o jeziku, se praviloma govori o turkestanskem, le redko se zgodi, da hoče biti avtor še bolj točen in omeni, da gre za uzbekistanščino, jezik največje narodne skupine znotraj Turkestancev. Še bolj nenavadno je, da je bila 162. turkestanska divizija sestavljena iz armenske, azerbajdžanske, gruzijske, severnokavkaške in turkestanske legije, sam Hans-Günther Seraphim pa je bil kapetan v armenski legiji. Kljub temu se razen Turkestancev, drugi narodi izjemno redko pojavljajo. Zaradi pomanjkanja natančnejših definicij v nemških virih ali dokumentih bo tudi v raziskavi uporabljeno splošno ime.

3 Newland, Cossacks in the German Army, 58, 90.

4 Pier Arrigo Carnier, L' armata cosacca in Italia (Milano: Mursia, 1993). Fabio Verardo, I cosacchi di Krasnov in Carnia (Udine: Aviani e Aviani, 2010). Newland, Cossacks in the German army. Enzo Collotti, Il Litorale Adriatico nel Nuovo ordine (Milano: Vangelista editore, 1975). Fabio Verardo, »Offesa all'onore della donna $<$ : le violenze sessuali durante l'occupazione cosacco-caucasica della Carnia 1944-1945 (Trst: Istituto regionale per la storia del movimento di liberazione nel Friuli Venezia Giulia, 2016). Michele Gortani, Il martirio della Carnia dal 14 marzo 1944 al 6 maggio 1945 (Tolmeč: Grafico »Carnia«, 1966).

5 Carnier, L' armata cosacca in Italia, 108-13. 
OZAK neposredno po kapitulaciji Italije opisal Tone Ferenc, ${ }^{6}$ Stefano Di Giusto pa raziskavo razširil na vse vojaške operacije na območju OZAK, v katerih je sodelovala divizija. ${ }^{7}$ Tudi zgodovinarki Marina Rossi ${ }^{8}$ in Nadežda Sergejevna Pilko ${ }^{9}$ sta obravnavali vojake 162. turkestanske divizije, vendar le v sklopu njihovega pobega $k$ slovenskim partizanom in nadaljnjega boja proti nacistični Nemčiji. Povojno problematiko kolaboracionistov iz Sovjetske zveze obravnava Jeffrey W. Jones, ki poskuša odgovoriti kako je sovjetska družba po koncu druge svetovne vojne gledala na kolaboracioniste, ${ }^{10}$ Tanja Penter pa se osredotoča na sodne procese proti njim. ${ }^{11} \mathrm{~S}$ problematiko muslimanov, ki so se bojevali za nacistično Nemčijo, se ukvarjata tudi zbornika Combatants of Muslim Origin in European Armies in the Twentieth Century: Far From Jihad ${ }^{12}$ in The Waffen-SS: A European History, ${ }^{13}$ kjer pa je ustanovitev nacističnih enot iz sovjetskih muslimanov le obrobnega pomena. Na Sovjetsko zvezo usmerita pogled šele članka Manfreda Zeidlerja ${ }^{14}$ in Davida Mortadela, ${ }^{15}$ vendar se oba osredinjata na Kavkaz in tamkajšnje pomožne policijske enote, ki so jih tam ustanovili nacisti. Na Turkestane in njihovo sodelovanje z nacisti se je posredno usmeril Charles W. Hostler, ${ }^{16} \mathrm{ki} \mathrm{je} \mathrm{svoj}$ članek napisal $\mathrm{v}$ času hladne vojne in poskušal dokazati, da so prebivalci Turkestana skrajno nezadovoljni s sovjetsko oblastjo, kar naj bi med drugim dokazovala tudi njihova kolaboracija z Nemci. Delo, ki med vsemi še najbolje prikaže odnos Turkestanov do nacistov, je Germany and Turkestanis during the course of the World War II (1941 -1945) Halila Buraka, ki se posveča predvsem političnemu vprašanju Turkestana, veliko manj pa se poglobi v tematiko vojaške narave.

Zgoraj navedena dela se ukvarjajo z boljševiškim zatiranjem turkestanskega nacionalizma in muslimanske vere, nacistično uporabo 162. turkestanske divizije v bojih proti partizanom, pobege med slovenske partizane, odnosom sovjetskih sodržavljanov do kolaboracionistov in sodnimi procesi ob povratku nazaj v Sovjetsko zvezo ter dajejo dobro podlago za razumevanje tematike. Česar pa v delih skoraj ni mogoče zaslediti je potek rekrutacije in urjenja turkestanskih kolaboracionistov. O tej temi je iz objavljenih del mogoče izvedeti le nekaj stavkov o vadbišču v Neuhammerju, o rekrutaciji

6 Tone Ferenc, Kapitulacija Italije in narodnoosvobodilna borba $v$ Sloveniji jeseni 1943 (Maribor: Obzorja, 1967).

7 Stefano Di Giusto, Operazione Adriatisches Küstenland: Udine Gorizia Trieste Pola Fiume e Lubiana (Videm: LithoStampa Pasian di Prato, 2005).

8 Marina Rossi, Soldati dell'armata rossa al confine orientale, 1941-1945 con il diario inedito di Grigorij Žiljaev (Gorizia: LEG, 2014).

9 Nadežda Pilko, Slovenija v gody okkupacii 1941-1945 gg. (Sankt Peterburg: Aletejja, 2009), 134-39.

10 Jeffrey W. Jones, »'Every Family Has Its Freak'. Perceptions of Collaboration in Occupied Soviet Russia, 19431948,« Slavic Review, št. 4 (2005): 747-70.

11 Tanja Penter, $\gg$ Collaboration on Trial: New Source Material on Soviet Postwar Trials against Collaborators, « Slavic Review, št. 4 (2005): 782-90. Tanja Penter, »Local Collaborators on Trial: Soviet War Crimes Trials under Stalin (1943-1953), « Cahiers du Monde russe, št. 2/3 (2008): 341-64.

12 Xavier Bougarel, Raphaëlle Branche in Cloé Drieu, ur., Combatants of Muslim Origin in European Armies in the Twentieth Century. Far From Jihad (London: Bloomsbury Publishing Plc, 2017).

13 Jochen Böhler in Robert Gerwarth ur., The Waffen-SS: A European History (Oxford: Oxford University Press, 2017).

14 Manfred Zeidler, $\gg$ Das 'kaukasische Experiment'. Gab es eine Weisung Hitlers zur deutschen Besatzungspolitik im Kaukasus?,« Vierteljahrshefte für Zeitgeschichte, št. 3 (2005): 475-500.

15 David Mortadel, »Islam and Germany's War in the Soviet Borderland 1941-1945,« Journal of Contemporary History, št. 4 (2013): 784-820.

16 Charles W. Hostler, »The Turks and Soviet Central Asia,« Middle East Journal, št. 3 (1958): 261-69. 
pa praktično ničesar. Da bi raziskava zapolnila to vrzel, se opira predvsem na arhivsko gradivo iz nemškega vojaškega arhiva v Freiburgu (Bundesarchiv Militärarchiv oz. BArch). Med viri je treba poudariti fond 162. turkestanske divizije (RH-26-162), fond generala Oskarja von Niedermayerja ${ }^{17}$ (N 122-6) in spomine poveljnika 13. čete 303. polka Hansa Güntherja Seraphima, ${ }^{18}$ ki je po vojni postal predavatelj mednarodnega prava na göttingenski univerzi ${ }^{19}$ in med drugim napisal spomine o svojem medvojnem delovanju znotraj 162. turkestanske divizije.

\section{Nacistična rekrutacija rdečearmejcev}

Vsako vojno poleg fizičnega spopada med stranema spremlja še propagandni boj, ki se je v času druge svetovne vojne bíl predvsem po časopisju, letakih in radiu. V tem boju želi vsaka vpletena stran s propagando prepričati svoje ljudstvo in tujino, da so njeni razlogi za vpletenost $\mathrm{v}$ vojno pravični. Pri tem se praviloma sklicuje na obrambo interesov naroda, ki ga zastopa. Ob spopadu nacistične Nemčije in boljševiške Sovjetske zveze, je propaganda obeh držav prešla na popolnoma novo raven.

Nacistična stran je med svoje vojake širila letake o nujnosti obrambe evropske civilizacije, nemškega načina življenja in vse Evrope pred boljševizmom. ${ }^{20} \mathrm{Hkrati}$ je med rdečearmejce s propagando poskušala vnesti dvom o smiselnosti bojevanja. Tako so med sovjetskimi vojaki krožili letaki o obupnem pomanjkanju hrane v Sovjetski zvezi, visokih cenah kruha, vojaških porazih Rdeče armade in neizbežnosti nacistične zmage. Propagandni letaki so poskušali rdečearmejce pomiriti in postaviti Stalina na laž: »Vi se bojite prebežati k nam, ker vam vaši voditelji pravijo, da Nemci sovjetskim vojakom režejo nosove in ušesa.« Namesto tega so letaki vabili: »Pridi k nam. S tem rešiš samega sebe, Rusijo in svojo družino. $\ll^{21}$

Nacisti so v prvem obdobju želi vojne uspeh za uspehom. Vendar pa so kmalu po prvih nemških porazih pred Moskvo začeli po zbirnih taboriščih za vojne ujetnike na Poljskem in v Ukrajini krožiti nacistični propagandisti z namenom rekrutiranja prostovoljcev, ki bi se bili pripravljeni bojevati za Tretji rajh. Nenavadno je, da je prav nacistični ideologiji, ki je močno poudarjala rasno čistost, uspelo privabiti veliko število vojakov nasprotne države, ki so prestopili na njeno stran. Za to je več razlogov, od idealističnega protiboljševizma in religioznosti do želje po osvoboditvi svoje domovine izpod sovjetske nadvlade ter nenazadnje zaradi preproste preračunljivosti. ${ }^{22}$ Vendar pa je bil daleč najpomembnejši razlog gola želja po preživetju, kar kaže na to, da odločitev prostovoljcev za pridružitev Wehrmachtu v določenem smislu ni bila prostovoljna. Razmere v taboriščih za vojne ujetnike so bile tako slabe, da so ujetniki pogosto prosili

17 Nemški general, diplomat in pustolovec (rojen v Freisingu 1885; umrl v Vladimiru, Sovjetska zveza, 1948).

18 Nemški častnik, zgodovinar in pravnik (rojen v Königsberg 1903; umrl v Göttingenu, 1992).

19 Newland, Cossacks in the German Army, 38.

20 BArch, MSG 2-12202, 458.

21 PAAA, Pol XIII-R 105186.

22 BArch, MSG 2-12202, 410. 
Nemce, naj jim dajo katerokoli delo, samo da se izognejo gotovi smrti v taborišču. ${ }^{23}$ $\mathrm{Z}$ naraščanjem nemških smrtnih žrtev so poveljniki Wehrmachta dopuščali vključitev sovjetskih ujetnikov v nacistični vojaški sistem. Sovjetskim ujetnikom so bila dodeljena enostavna dela, bili so kuharji ali vozniki, ki niso predstavljali grožnje Tretjemu rajhu. ${ }^{24}$ Druga skupina kolaboracionistov so bili večinoma predstavniki neruskih narodov, ${ }^{25} \mathrm{ki}$ so po nacističnem mnenju imeli željo po boju proti sovjetski oblasti. ${ }^{26}$

$\mathrm{Z}$ namenom novačenja sovjetskih vojnih ujetnikov je bil leta 1942 sestavljen splošen vprašalnik, ki so ga izpraševalci sami prilagodili za potrebe posamezne narodne in verske $\mathrm{e}^{27}$ skupine. Primeri vprašanj so bili:

1. Si poročen? 2. Imaš otroke? 4. Kje živiš? 6. Si veren? 7. Si zadovoljen s sovjetskim režimom? 10. Kaj si po poklicu? 12. Katere jezike govoriš? 13 . Si že kdaj potoval? ... ${ }^{28}$

Le na koncu je vprašalnik prešel iz splošnosti in dal nemškemu izpraševalcu nekaj specifičnih napotkov. Pripadnikom kavkaških ljudstev so postavili vprašanje: Kakšen je tvoj odnos in odnos tvojega naroda do ruskega naroda?, kozake so povprašali po mnenju o posledicah kolektivizacije, Uzbeke (Turkestane) pa o prisilnem delu, še posebej glede izgradnje velikega rečnega kanala v dolini Fergane..$^{29}$ Do jeseni 1942 so na ta način nacisti pridobili dovolj rekrutov za novoustanovljeno turkestansko legijo. ${ }^{30}$ Tedaj je poveljnik legije Oskar von Niedermayer pripravil analizo rezultatov vprašalnika rekrutov, nad katerimi je dobil poveljstvo. ${ }^{31}$ Analiza nam daje zanimiv vpogled v lastnosti, ki so jih izpraševalci iskali (in po svojem mnenju tudi našli) ${ }^{32}$ pri rekrutih.

Oče povprečnega prostovoljca je bil praviloma kolhozni ali tovarniški delavec, manjši obrtnik ali v najboljšem primeru učitelj. Pred boljševiško revolucijo je bil pogosto premožnejši posestnik ali govedorejec, vendar je zaradi kolektivizacije obubožal in je posledično sebi in svoji družini lahko zagotovil le golo preživetje. »Le redko lahko govorimo o znosnih življenjskih razmerah $v$ hiši staršev. « Večina staršev, še posebej muslimanov, je bila verna, vendar pa je zaradi 25 let boljševiške propagande vera mlajše generacije začela bledeti. Rekruti so obiskovali večinoma le osnovno šolo, univerzitetno izobraženih skoraj ni bilo. Turkestani večinoma niso znali tujih jezikov in tudi ruščina jim je delala težave, saj je le majhen odstotek prostovoljcev aktivno obvladal

23 Ibidem, 459.

24 Imenovani so jih hiwiji (Hilfswillige). Na svojih uniformah so imeli našitke, na katerih je pisalo »V službi nemškega Wehrmachta. (In Dienst der deutschen Wehrmacht) «. - Halil Sakal Burak, Germany and Turkestanis During the Course of the World War II (Ankara: [H. Burak Sakal], 2010), 91.

25 Med drugo svetovno vojno se je za Tretji rajh bojevalo 1,2 milijona državljanov Sovjetske zveze od tega 800.000 znotraj Wehrmachta, 300.000 v okviru lokalnih policij, 150.000 pa v vrstah Waffen-SS. Največjo je bilo etničnih Rusov (približno 300.000), sledili so Balti (221.000), Ukrajinci (220.000), Turkestani (180.000), Kavkazci (110.000), Tatari (60.000), Kozaki (53.000), Belorusi (50.000) in Kalmiki (5.000). Böhler in Gerwarth, The Waffen-SS, 168.

Biti Rus je pomenilo enako kot biti Sovjet, zato so mnogi kavkaški in turkestanski narodi sovjetsko oblast videli le kot nadaljevanje ruskega imperializma. - Tony Judt, Povojna Evropa 1945-2005 (Ljubljana: Mladinska knjiga, 2007), 746.

27 V vprašalniku ni niti enega vprašanja glede vere, temveč se usmeri predvsem na narodnostno pripadnost.

28 Fragebogen für Legionäre. BArch, RH-26-162-20.

29 Fragebogen für Legionäre. BArch, RH-26-162-20.

30 Do ustanovitve 162. turkestanske divizije so rekrute v poročilih imenovali legionarji, po ustanovitvi divizije pa prostovoljci.

31 Auswertungsergebnis der Fragebogen für Legionäre 12. 10. 1942. BArch, RH-26-162-20.

32 Težko je reči koliko od tega so bile laži vojnih ujetnikov, ki so si želeli samo priti do boljše prehrane in oblačil. 
ruščino, ustno pa se je lahko v ruskem jeziku sporazumevalo od 30 do 40 odstotkov rekrutov. ${ }^{33}$ Zaradi neznanja tujih jezikov so lahko nacisti med približno 7.000 primernimi turkestanskimi rekruti dobili le 28 prevajalcev, ki so znali nekaj nemščine, in še znanje teh tudi po prihodu iz prevajalske šole pogosto ni bilo na zadovoljivi ravni. ${ }^{34}$ Skoraj nobeden od rekrutov $\mathrm{v}$ svojem življenju ni potoval iz svoje republike in še potovanja tistih, ki so šli ven, so »večinoma primitivna «. Nikoli še niso videli »moderne civilizacije kot so tram, tovarne, nebotičniki ali moskovska podzemna železnica $\ll .{ }^{35} \mathrm{To}$ skromnost so Nemci videli tudi pri izobraženih legionarjih, kot je primer armenskega učitelja iz Erevana, ki je za prizadevno delo dobil brezplačno potovanje do Krasnodarja in Rostova. S tem, da so nacisti iskali rekrute, ki v življenju skoraj niso potovali, so želeli nanje narediti kar se da velik vtis, ko bi ti prišli v Nemčijo. ${ }^{36}$ Še posebej so svojo propagando usmerjali v prevajalce in propagandiste, ki so v časopisu namenjenem turkestanskim prostovoljcem, rojake bodrili za borbo na strani Tretjega rajha. ${ }^{37}$

Rekruti so Rdečo armado opisovali kot slabo oskrbovano, še posebej so poudarjali, da na fronti do njih ni prišlo dovolj hrane in zimskih oblačil. Pošta ni delovala in veliko pisem se je preprosto izgubilo. Sanitetnemu oddelku je primanjkovalo osebja, zato so morali pogosto tudi težko ranjene pustiti umreti kar na bojičču. Častniki Rdeče armade so dobivali boljšo hrano kot navadni vojaki ter bili v večji meri ruske narodnosti in člani komunistične partije, pogosto naj bi bili pijani in brez pravega odnosa do svojega moštva. Še boljši položaj so imeli politični komisarji Rdeče armade, ki so jim rekruti pripisovali slabe odnose z moštvom in s poveljujočimi v enoti, saj so se vmešavali v vojaške odločitve, kar je privedlo do trenj. $\gg$ Zanimiva pa je pripoved enega od legionarjev, ki je imel dobre odnose s svojim političnim komisarjem, in ta mu je nekoč na štiri oči priznal, da Sovjetska zveza nima nobene možnosti za zmago, kljub temu da med propagandnimi urami trdi drugače. ${ }^{38}$ Politični komisarji so bili, podobno kot častniki, po rodu največkrat Rusi, ki v bojih skoraj nikoli niso sodelovali. Namesto tega naj bi se postavili šest do osem kilometrov za fronto in s pištolo ali mitraljezom streljali na rdečearmejce, ki so bežali z bojišča.

Podobno kot o političnih komisarjih so rekruti izpraševalcem slabo govorili tudi o sovjetski oblasti. »Pred revolucijo sta bila življenje in prehrana boljša, sedaj pa so samo še nezadostna plača in visoki davki. $V$ mestu ni mogoče najti dovolj velikega stanovanja, medtem ko na podeželju kronično primanjkuje zdravnikov, zaradi česar razsajajo malarija, tifus in sifilis. $\ll{ }^{39}$ Nova oblast naj bi veliko pozornost namenjala le komunistični vzgoji, kjer je pri pouku zgodovine močno poudarjala zgodovino bolǰ̌evizma.

33 BArch, MSG 2-12202, 473.

34 Bericht über das Dolmetscherweise innerhalb der Division in der Zeit vom 1. 10. bis 31. 12. 1942. 8. 2. 1943. BArch, RH-26-162-20.

35 Auswertungsergebnis der Fragebogen für Legionäre 12. 10. 1942. BArch, RH-26-162-20.

36 Še posebej so tu mišljeni propagandisti.

37 Podobno so bili tudi slovenski domobranski propagandisti poslani na štirinajstdnevno potovanje po Nemčiji. Boris Mlakar, Slovensko domobranstvo: 1943-1945: ustanovitev, organizacija, idejno ozadje (Ljubljana: Slovenska matica, 2003), 352.

38 Auswertungsergebnis der Fragebogen für Legionäre 12. 10. 1942. BArch, RH-26-162-20.

39 Ibid. 
Na splošno je naciste močno zanimalo, kaj vojni ujetniki sploh vedo o zgodovini, vendar so bili presenečeni, da razen Armencev sploh niso poznali zgodovine lastnega naroda. Poznali niso niti ruske zgodovine, ko so jim vladali carji, in le redko kdo je poznal kakšnega drugega carja razen Petra I., Katarine Velike in zadnjega carja Nikolaja II. Prav nasprotno pa so bile vsem dobro poznane zmage proti $\gg$ belemu $\ll$ generalu Aleksandru Kolčaku in njegovim pomočnikom v času državljanske vojne. ${ }^{40}$

Vojni ujetniki, ki jih je zajel Wehrmacht, so vrsto let poslušali sovjetsko propagando, zato so izpraševalci podrobno spraševali, kako potencialni rekruti vidijo Tretji rajh. Tudi glede teh vprašanj niso pokazali velike razgledanosti. Nekateri so imeli Nemčijo za zmagovalko v prvi svetovni vojni, eden od rekrutov pa je celo mislil, da se država nahaja v Aziji. Vsem je bilo znano, kdo je Hitler, vendar pa o njem niso znali povedati česa več kot imena in priimka. Nekateri so vedeli, kdo je Joachim von Ribbentrop, ${ }^{41}$ ki je leta 1939 obiskal Moskvo, eden od legionarjev pa je slišal celo za poveljnika Afrikakorps Erwina Rommla. Kar so vedeli o Nemčiji, je skoraj izključno prihajalo iz sovjetske propagande, kjer je bila predstavljena kot fašistično-kapitalistična država. Za izpraševalce in Niedermayerja pa je bilo zanimivo dejstvo, da so po podpisu dogovora Molotov-Ribbentrop sovjetske oblasti spremenile odnos do Tretjega rajha in ga niso več imenovale »fašistični, ampak nacionalsocialistični, kar pomeni, da je Nemčija ravno tako socialistična kot Rusija, le da je zastopala svoje nacionalne cilje $\ll^{4}{ }^{42}$ Kratko prijateljstvo je v trenutku izginilo, ko je nacistična Nemčija izvedla operacijo Barbarossa, in ponovno so jo prikazovali kot fašistično-kapitalistično. Legionarjem, ki so prihajali iz Turkestana in s Kavkaza, je bila Nemčija španska vas in le eden je imel z njo posredne stike. Stric tega prostovoljca je bil kapitan na ladji, ki je pogosto potovala $\mathrm{v}$ Hamburg, in je o svojem prebivanju v Nemčiji pogosto pripovedoval nečaku.

Niedermayerjevo poročilo nakazuje, da so nacistični izpraševalci praviloma iskali neizobražene in revne može, katerih starši so s prihodom boljševiške oblasti obubožali in so imeli željo po zamenjavi oblasti. Veliko legionarjev se je tega zavedalo in zato prikrojilo svoje zgodbe, da bi bili dovolj sprejemljivi in se s tem rešili grozljivih življenjskih razmer v zbirnih taboriščih za sovjetske vojne ujetnike. To so opazili tudi izpraševalci, ki so ugotovili, da je »za legionarje vstop v legijo le prvi korak k boljši oskrbi, prehrani in tudi obleki ... Želja po osvoboditvi domovine je le redko na prvem mestu, skoraj vedno na drugem mestu. « Ta opažanja so se ponovila še pri dveh vprašanjih. Pri vprašanju »Kakšna naj bo oblast v osvobojeni domovini? « na kar se je večina odgovorov glasila: »taka kot nemška «. Niedermayer je ob tem pripomnil, da je to verjetno iz vljudnosti, kar se je ponovilo tudi pri odgovorih na vprašanje: $\gg$ Kaj ti je najbolj všeč pri Wehrmachtu? « Odgovor »se je velikokrat - pogosto verjetno zaradi vljudnosti glasil: vse $\ll .{ }^{43}$ Poveljnik turkestanske legije in potem 162. turkestanske divizije Oskar von Niedermayer se je zavedal, da prostovoljci ne izkazujejo nobene posebne želje po bojevanju in da so bili predvsem srečni, da so živi in zdravi prišli iz zbirnih taborišč.

\footnotetext{
40 Ibid.

41 Zunanji minister nacistične Nemčije (rojen v Weselu, 1893; umrl v Nürnbergu, 1946).

42 Auswertungsergebnis der Fragebogen für Legionäre 12.10.1942. BArch, RH-26-162-20.

43 Auswertungsergebnis der Fragebogen für Legionäre 12.10.1942. BArch, RH-26-162-20.
} 


\section{Nacistične priprave na integracijo Turkestanov v Wehrmacht}

Nemško osebje, ki je bilo dodeljeno nastajajočim enotam, je pričakovalo idealiste, pripravljene na osvoboditev svoje domovine izpod boljševistično-ruskega jarma. ${ }^{44}$ Kot poroča eden od častnikov, so namesto zagnanih $\gg$ kameradov《 dobili $\gg$ tuje obraze, pogosto mongolskega tipa in neprijetnega motečega vonja, ki poudarja odvraten vtis o tuji rasi... Potem so bila tu raztrgana in umazana oblačila - večinoma uniforme Rdeče armade. Masa se je tesno stiskala skupaj. Nobenih bistvenih podrobnosti v masi ljudi. $\ll{ }^{45}$

Že od samega začetka je obstajalo ločevanje na turkestanski in nemški del legije oziroma divizije in le sreča v nesreči je bila, da je imelo veliko Nemcev v novonastali legiji že izkušnje s Turkestanci, saj so bili to večinoma nekdanji pazniki teh zapornikov, ki so čez noč postali njihovi tovariši. ${ }^{46} \mathrm{Ti}$ pazniki pa so bili primerni za vse drugo, le za urjenje Turkestancev ne. To so bili stari nemški častniki iz prve svetovne vojne, ki jih je Wehrmacht zaradi pomanjkanja vojakov vpoklical nazaj v službo. Njihovo delo ob vpoklicu je bilo, da v taborišču pazijo, da vojni ujetniki ne bi zbežali. Zdaj, po množični smrtnosti in rekrutaciji dobršnega dela preostalih ujetnikov je bila tem starim častnikom dodeljena naloga, naj sestradane in slabo oblečene Turkestance spremenijo v vojake, ki bi bili željni boja proti Sovjetski zvezi. Prva naloga urjenja je bila med rekruti dobiti tiste, ki so znali nemško, in jih izučiti za prevajalce iz nemškega v uzbeški in azerbajdžanski jezik. Prevajalci so bili ključni, saj so predstavljali vezni člen med nemškim in turkestanskim moštvom. Težava je bila v tem, da so jih med turkestanskimi vojnimi ujetniki od skupno $6668^{47}$ lahko dobili samo 28 , ki so bili kolikor toliko primerni za prevajanje. Eden izmed rekrutov, ki so ga izbrali samo zaradi znanja nemščine, je bil Mehdi Huseynzade, pozneje bolj znan tudi kot Mihajlo. Ta je govoril skoraj brezhibno nemščino, ${ }^{48}$ saj je na Pedagoškem inštitutu v Bakuju študiral literaturo in jezike. ${ }^{49}$ Znanje nemščine ga je naredilo nepogrešljivega, zato so nacisti spregledali kriterije, ki so si jih zastavili glede rekrutacije sovjetskih ujetnikov. Mehdi je študiral na univerzi, pred vojno je bil član Komsomola, nekaj časa je živel v Leningradu in bil vpoklican v Rdečo armado, kjer je opravil oficirsko šolo in dobil naziv vodje minometalskega voda. ${ }^{50}$ Vodja 13. čete 303. turkestanskega polka Hans Günther Seraphim se spominja, da je, preden je prvič šel med svoje nove turkestanske vojake, najprej poizvedel, kdo je imel v Rdeči armadi častniški čin, da bi ga še posebej nadzoroval. O tem razen svojima podčastnikoma Petersu in Schneidereitu ni povedal nikomur, da Turkestanci ne bi

44 BArch, MSG 2-12202, 479.

45 Ibid., 409.

46 Ibid., 427.

47 Di Giusto, Operazione Adriatisches Küstenland, 109.

48 Rossi, Soldati dell'armata rossa al confine orientale, 225.

49 Ibid., 271.

50 Ciril Zupanc, Mihajlo, obveščevalec in diverzant IX. korpusa (Nova Gorica: Goriški muzej, 2007), 6. 
česa posumili. ${ }^{51}$ Pri Mehdiju nemški častniki niso bili dovolj pozorni na te podrobnosti, kar mu je omogočilo, da je 6. februarja 1944 z Opčin, kjer se je nahajala njegova enota, zbežal k slovenskim partizanom, izvedel vrsto odmevnih bombnih napadov in pripravil prebeg še nekaterih svojih soborcev. ${ }^{52}$

Usposabljanje tega majhnega števila prevajalcev je bilo eno najpomembnejših nalog znotraj divizije, zaupana je bila nemškemu vodji prevajalcev. ${ }^{53}$ Ta je moral izpopolnjevati znanje nemščine turkestanskih prevajalcev, jih ocenjevati in voditi seznam prevajalcev, v katerega se je zapisovalo, ali so storili kaj neprimernega. Učenje nemščine je bilo za prevajalce na prvem mestu, zato so lahko izpustili daljša vojaška urjenja, ki so bila obvezna za ostale prostovoljce. ${ }^{54}$ Obratno je vodja prevajalcev imel tudi dve uri tedensko predavanja iz ruščine ${ }^{55}$ za nemške vojake, ki so se morali med predavanji naučiti vsaj 300 ruskih besed. To so bili skoraj izključno vojaški ukazi, medtem ko se jim s težjimi povedmi in slovnico skoraj ni bilo treba ukvarjati. ${ }^{56}$ Učni list teh predavanj za nemško moštvo je bil videti takole:

Wo eigene Artillerie? ГАе наша артимлерия?

Stärke des Feindes? Какой силы враг?

$\begin{array}{ll}\text { Gefecht } & \text { Бой } \\ \text { Feuer } & \text { Огонь } \\ \text { schießen } & \text { Стремять } \\ \text { schnell } & \text { Скоро }\end{array}$

Največji promotor uporabe ruščine v odnosih s turkestanskimi prostovoljci je bil general in pisec zgoraj navedenih poročil, Oskar von Niedermayer, ki je od nemških častnikov, ki so bili tega sposobni, zahteval, da vsaj v začetku poročajo v ruščini, saj bi tako kar največji krog nemških ${ }^{58}$ in turkestanskih častnikov in podčastnikov razumel zadane naloge.

Značilna je epizoda, ko je poročnik 13. čete 303. turkestanskega polka Peters, ki je bil tisti dan zadolžen za poročanje, stopil pred Oskarja von Niedermayerja in mu $v$ ruščini zdrdral poročilo. General je bil navdušen nad tekočo ruščino in mu je začel $v$ tem jeziku govoriti. Ko je general končno opazil, da od Petersa ni odgovora, ga je vprašal: »Ali me ne razumete? « Poročnik pa mu je odgovoril: »Ne, gospod general.« Poveljnikovo razočaranje je bilo veliko, njegov glas pa je v ostrem tonu nadaljeval: »Ja, ampak kako, saj ste lahko poročali v tekoči ruščini? « Peters mu je sramežljivo

51 BArch, MSG 2-12200, 21.

52 Zupanc, Mihajlo, obveščevalec in diverzant IX. korpusa, 7.

53 Dolmetscherführer.

54 Dienstanweisung für Dolmetscher. BArch, RH-26-162-20.

55 Turkestanci so govorili številne jezike, od azerbajdžanskega, uzbekistanskega, kazahstanskega itd., zato se je nacističnemu vodstvu zdelo najprimerneje, da se Nemci naučijo jezika, ki ga razume največ prostovoljcev, torej ruščine.

56 Grundsätze der Ausbildung des Turk-Verbandes. BArch, RH-26-162-20.

57 Prevod zgornjih povedi: Kje naša artilerija?, Kakšne sile sovražnik?, boj, ogenj, streljati, hitro. Učenje ruščine je bilo skrajno poenostavljeno, saj so bili glagoli in sklanjatve pogosto izpuščeni, kar je razvidno iz vprašanj o lokaciji artilerije in sovražnikovi moči. - Dienstanweisung für Dolmetscher. BArch, RH-26-162-20.

58 V enote, kjer so sovjetski vojni ujetniki imeli pomembno vlogo, je Wehrmacht, če je le bilo mogoče razporedil nemške častnike z vsaj osnovnim znanjem ruščine. Kljub temu pa so se izvajali tečaji ruščine za nemške vojake. - BArch, MSG 2-12200, 33. 
odvrnil: »Gospod general, poročilo, namenjeno vam, sem si napisal in se ga naučil na pamet.« Generalova jeza je postajala vse večja: »Ali niste prav nič razumeli tega, o čemer ste poročali!? « Poročnik mu je iskreno odvrnil: »Ne, gospod general. Mi smo se te stvari naučili na pamet.« Generalove metode pri komunikaciji so ga osramotile pred častniki, zato je začel kričati: »Potem pa vam ukazujem, da se teh stvari naučite. Kaznujem vas $\mathrm{s}$ tremi dnevi hišnega pripora!!! $\ll^{59} \mathrm{Ti}$ absurdni primeri so prispevali k opuščanju ruščine v diviziji, medtem ko je nemščina iz dneva v dan imela večjo vlogo. Turkestanci so na pohodih še vedno peli svoje pesmi in pri »najbolj priljubljenih napevih « so se jim pridružili tudi nemški vojaki, ${ }^{60}$ vendar je postalo jasno, da je nemščina $\mathrm{v}$ turkestanski diviziji glavni jezik.

Oskar von Niedermayer po mnenju Dossene, ki je pisal o Turkestancih v nemški vojski, ni bil najboljša izbira za poveljnika na divizijski ravni, ${ }^{61}$ saj je večino svoje kariere preživel na položaju univerzitetnega profesorja in na diplomatskih misijah po svetu. ${ }^{62}$ Bavarec je študiral geografijo, geologijo in filologijo na univerzi v Erlangenu ${ }^{63}$ ter so ga zaradi njegovega jezikovnega znanja med letoma 1912 in 1914 poslali na raziskovalno potovanje po Perziji in Indiji. Ker je služil tudi v nemški vojski, ga je ta ob začetku prve svetovne vojne najprej poslala v Perzijo, da bi tam organiziral vstajo proti Britancem, leta 1915 pa je dobil nalogo vodenja odprave, ki bi afganistanskega emirja prepričala, da napade Britansko Indijo. Na poti do Afganistana je s svojo odpravo zbežal številnim britanskim zasedam, sčimer je zrasel njegov ugled, vendar pa mu na koncu emirja ni uspelo pridobiti na nemško stran. ${ }^{64}$ Med obema vojnama je najprej deloval v Moskvi kot predstavnik Reichwehra, potem pa še kot profesor na Humboldtovi univerzi (tedanji berlinski univerzi), kjer je predaval vojaško politiko in geografijo. ${ }^{65}$ Ob začetku druge svetovne vojne so ga leta 1940 najprej poslali v Grčijo in Turčijo, potem pa še za tri mesece na Japonsko. Ob predpripravah na operacijo Barbarossa so ga zaradi dobrega poznavanja Sovjetske zveze, še posebej njenega osrednjega azijskega dela, imenovali za inštruktorja v pehotni šoli, dokler ni 1. maja 1942 prevzel poveljstva prvih prostovoljskih enot, oblikovanih iz sovjetskih ujetnikov. ${ }^{66}$ Tako so pustolovca, čigar akcije so predhodno temeljile na majhnemu številu vojakov in hitrih premikih, imenovali za poveljnika cele 162. turkestanske divizije, katere prva vojaška naloga je bila »očistiti« območje OZAK boljševiškega partizanstva, ki je tako kot nekoč on v azijskih stepah, izvajalo sabotaže ter poskušalo organizirati ljudsko vstajo proti okupatorju.

Da bi se prostovoljci za Tretji rajh kar najbolje bojevali proti partizanom na

59 BArch, MSG 2-12200, 50, 51

60 Ibid., 56

61 Paolo Dossena, Hitler's Turkestani Soldiers: A History of the 162nd (Turkistan) Infantry Division (Solihull: Helion \& Company, 2015), 173

62 Seraphim Oskarja von Niedermayerja ni maral. V spominih ga opisuje kot med vojaki nepriljubljenega in vojaško popolnoma nesposobnega. - BArch, MSG 2-12200, 244-47.

63 Poleg nemščine je govoril še francoski, angleški, ruski, arabski, perzijski in turški jezik. - BArch, PERS 6-1679

64 Thomas L. Hughes, »The German Mission to Afganistan. 1915-1916, « German Studies Review, št. 3 (2002): 447-76. Hans-Ulrich Seidt, $\gg$ From Palestine to the Caucasus-Oskar Niedermayer and Germany's Middle Eastern Strategy in 1918, « German Studies Review, št. 1 (2001): 1-18

65 Seidt, $\gg$ From Palestine to the Caucasus-Oskar Niedermayer, $\ll 2$.

66 BArch, PERS 6-1679. 
okupiranih ozemljih, je von Niedermayer s svojimi kolegi sestavil navodila za urjenje turkestanskih enot. ${ }^{67}$ Turkestanci so se morali nauciti, kako deluje bojna enota $\mathrm{v}$ napadu in kako deluje takrat, ko je treba postaviti obrambni položaj. Bojni načrt se je med bojem lahko spremenil, in da bi prostovoljci kar se da jasno razumeli, kaj hoče nemški poveljnik od njih, so od njega zahtevali, da uporablja čim enostavnejše stavke, ki se jih je naučil pri pouku ruščine. Tudi na splošno urjenje turkestanskih čet ni bilo $\gg$ tako kot urjenje nemških enot $\ll{ }^{68}$ Pri urjenju ni smelo biti nobene teorije, temveč samo kar se da jasno in poenostavljeno praktično urjenje. Ker je bil poudarek na napadu in obrambi, so jih nemški častniki urili v bojnih pohodih, razporeditvi enote ob napadu in razvoju boja, kjer je bilo največ pozornosti namenjeno poteku boja v gozdu. Turkestancem pa se ni bilo treba uriti $v \gg$ težjih oblikah boja, kot sta na primer prečkanje reke, napad proti tankom in utrdbam «, ob koncu vsakega urjenja pa je bil potreben pogovor, prav tako je bilo treba $\gg$ legionarje pohvaliti za njihov napredek. $\ll^{69}$

Nemci so $\mathrm{z}$ vojaškimi urjenji kolaboracioniste želeli naučiti dolžnosti vojaka Wehrmachta, von Niedermayer pa je izjavil: »Pri tej nalogi se ne pričakuje posebnih težav.« Veliko več težav je bilo pričakovati pri »prepričevanju bivših rdečearmejcev, da se bojujejo na nemški strani $\ll^{70}$ Vsi rekruti so se rodili v Sovjetski zvezi, tam hodili $\mathrm{v}$ šole, postali pionirji, čez celo mladost pa jih je spremljala boljševiška propaganda. To propagando, ki je bila vrsto let del vsakdanjika prostovoljcev, so želeli nacisti nadomestiti z novim svetovnim nazorom. $\mathrm{V}$ ta namen so pri rekrutih vzbujali domoljubna čustva, idejo o neodvisnosti Turkestana, boljšem gospodarskem razvoju, ki bi ga samostojnost prinesla, itd. Poleg domoljubja so želeli pri prostovoljcih kar se da spodbuditi tudi islamsko vero, ${ }^{71}$ kajti veljalo je prepričanje, $\gg$ da so prepričani muslimani lahko dragoceni in zaupanja vredni vojaki.$^{72}$ Von Niedermayer se je zavedal, da nacistična ideologija ne sovpada s turkestanskimi interesi, zato so se morali predavatelji izogniti razglabljanju »o stanju znotraj Nemčije «. Ni se smelo razpravljati o položaju cerkve v Nemčiji, o Judih se je lahko govorilo le, da so imeli nekoč moč, vendar se strogo nikoli ni smelo reči, da so kadarkoli imeli oblast. Namesto tega je bilo treba poudarjati zunanjepolitični cilj Tretjega rajha, da bo uničil Sovjetsko zvezo, na pogorišču katere bo nastal tudi svobodni Turkestan. Predavatelji so morali biti pri svojih urah spretni, da so se lahko izognili neprijetnim temam, saj »če legionarji predavatelja zalotijo pri laži, mu ne bodo več zaupali $\ll{ }^{73}$ Ideološka predavanja so bila podkrepljena z mesečnimi poročili o stanju na fronti in propagandnimi časopisi Swoboda, Nowoje slowo, Signal, Nowy put, Azerbajdžan, Jeny Turkistan in Milli Turkistan, ki so morali biti prostovoljcem zmeraj na voljo.

67 Grundsätze der Ausbildung des Turk-Verbandes. BArch, RH-26-162-20.

68 Ibid.

69 Ibid.

70 Richtlinien für Schulungsvorträge. BArch, RH-26-162-20.

71 Nacisti islama niso promovirali samo med turkestanskimi rekruti, temveč tudi na zasedenih območjih Kavkaza in Krima, kjer so ponovno uvedli praznovanje kurban bajrama in ramadana. - Mortadel, Islam and Germany's War in the Soviet Borderland, 796.

72 Richtlinien für Schulungsvorträge. BArch, RH-26-162-20.

73 Ibid. 
Poleg ideoloških predavanj in časopisov so organizirali tudi plese, športne aktivnosti, petje in igre, ki naj bi spodbujale tovarištvo med turkestanskim in nemškim moštvom, za konec pa je von Niedermayer pripravil še obisk nemških mest, kjer bi bilo mogoče videti »pravo podobo nemške kulture in civilizacije $\ll{ }^{74}$

\section{Težave pri integraciji Turkestancev v nemški Wehrmacht}

Von Niedermayer je napisal navodila za urjenje prostovoljcev, v katerih nacizem in njegova ideologija sploh nista omenjena. Kljub temu pa ideologije ni bilo mogoče povsem zanikati. Nemški vojaki v turkestanski legiji so bili prepojeni z nacističnim rasizmom in so $v$ sovjetskih Turkestancih pogosto videli $\gg$ večinoma azijatski in primitiven narod $\ll .{ }^{75}$ Težaven odnos med Nemci in Turkestanci je v svojih spominih analiziral profesor in stotnik Hans Günther Seraphim, ${ }^{76}$ ko je prvega junija 1943 prišel $\mathrm{v}$ vadbeni kamp novoustanovljene 162. turkestanske divizije. ${ }^{77} \mathrm{~V}$ začetku junija se je v Neuhammerju (današnji Świętoszów na Poljskem) zbralo 14.148 vojakov, od tega je bilo 7.480 večinoma volksdeutsche ${ }^{78}$ Nemcev in 6.668 turkestanskih kolaboracionističnih prostovoljcev. ${ }^{79} \mathrm{Ta}$ sprememba razmerja je bila pogojena $\mathrm{z}$ željo po nadzoru nad usposabljanjem in tudis strahom pred uporom Turkestancev. Drugi sklep, ki ga je mogoče izpeljati iz novo vzpostavljenega številčnega razmerja, je dejstvo, da je bila kljub imenu divizije to večinsko nemška enota. Če so predtem turkestanske kolaboracionistične enote zapostavljali, saj niso želeli, da bi bile v breme nacistični vojni industriji, in so si morale orožje pridobiti, kot so vedele in znale, ${ }^{80}$ so zdaj res postale del nemške vojske.

Kljub vsemu pa to ni bila običajna bojna enota Wehrmachta, česar so se zavedali tudi nemški častniki. Poveljnik Seraphim je prvi dan urjenja zbral svoje podčastnike in jih nagovoril: »Tako kameradi, lahko si predstavljam, da ni bilo prav prijetno presenečenje. Vendar zdaj stvari ni več mogoče spremeniti. Sodelovati boste morali s turkestanskimi vojaki. Drugače niso tako slabi, kot se zdi iz njihove tuje zunanjosti. Jaz sem z njimi že skoraj leto dni in lahko vam to potrdim iz osebnih izkušenj. Drugače pa to ni pomembno. V Nemčiji ni dovolj vojakov. Zato moramo biti veseli, če se tuji prostovoljci odločijo, da se bojujejo na naši strani. Ne smemo jih pustiti kar samih. Brez nas ne gre. Torej je to za vas nagrada, ne pa kakšna kazen, da so vas poslali sem. $\ll^{81} \mathrm{~S}$ tem se je začelo nenavadno sobivanje nemških in turkestanskih vojakov.

Grundsätze der Ausbildung des Turk-Verbandes. BArch, RH-26-162-20.

BArch, MSG 2-12200, 34

Seraphim je bil poveljnik 13. čete 303. polka znotraj turkestanske divizije, njegove spomine pa hrani Vojaški arhiv v Freiburgu.

BArch, MSG 2-12200, 1

Dossena, Hitler's Turkestani Soldiers, 46.

Di Giusto, Operazione Adriatisches Küstenland, 109.

BArch, MSG 2-12202, 420

BArch, MSG 2-12200, 30. 
Med nemškimi in turkestanskimi vojaki je prihajalo do nesporazumov, ki so temeljili na verskih in kulturnih razlikah. Kot anekdotičen lahko omenimo dogodek, ko se je prvo skupno jutro v Neuhammerju stotnik Hans Günther ob šesti uri sprehodil po vadbišču in je do njega pritekel sudetski podčastnik Haida ter ves razburjen poročal: »Ja, predstavljajte si, gospod stotnik, šel sem v prostore prostovoljcev, da bi jih zbudil, vendar jih najmanj polovica kleči na starih vrečah na tleh in dela vaje ter govori nerazumljive stvari. $\ll{ }^{82}$ Turkestancev povprečen Nemec še nikoli ni videl, kaj šele, da bi jih videl ob jutranji molitvi. Ko je 303. polk, ki je bil del turkestanske divizije, z vadbišča v Neuhammerju odšel na pripravljalni pohod v trideset kilometrov oddaljeni Bunzlau (poljsko Bolesławiec), so nemški vaščani, ki so jim prišli nasproti, mislili, da gre za »Japonce, ki so prišli v Evropo, da bi pomagali Nemčiji . $^{83}$

Seraphim je pogosto poudarjal, da ni primerno iskati razlik med Nemci in Turkestanci, ${ }^{84}$ vendar si pred njimi ni bilo mogoče zatiskati oči. Turkestanci niso bili navajeni individualnosti, temveč so težili h kolektivu. Posamezne sobe, ki so nemškim vojakom zagotavljale nekaj zasebnosti, niso bile njihovim azijskim kolegom nikoli všeč, raje so imeli prostore, kjer ni bilo zidov ter so se lahko skupaj družili in zabavali. ${ }^{85}$ Nemški kolegi so o Turkestancih menili, da se ob jedi ne znajo pravilno vesti in da ne skrbijo za čistočo. Tako naj se na primer ne bi preveč ukvarjali s čiščenjem vojaške uniforme in čevljev in so na splošno veljali za lene. ${ }^{86}$ To je bila velika težava za njihove nadrejene, ki v nasprotju s von Niedermayerjevimi pričakovanji ${ }^{87}$ kolaboracionistom nikakor niso mogli vbiti v glavo večje discipline. Tudi najstrožji častniki so po nekaj poskusih obupali, da bi Turkestance naučili $\gg$ pruskih vrednot $\ll .{ }^{88}$ Če so jih častniki želeli disciplinirati in so jih poslali za nekaj dni v »arest «, so bili prostovoljci tega veseli, saj so se lahko »končno naspali in jim ni bilo treba opravljati dolgočasne službe « ${ }^{89}$ Nacisti so lahko disciplino med prostovoljci vzdrževali samo z odvzemom hrane in zmanjšanjem plače. ${ }^{90}$ Seveda ni bilo vse slabo. Čeprav so bili Turkestanci individualno slabi vojaki, ${ }^{91}$ so se kot enota relativno dobro izkazali. ${ }^{92}$ Prav tako so bili izurjeni strelci, obvladali so kamuflažo in orientacijo, kar so bile vse vrline, potrebne za preživetje v stepi ${ }^{93} \mathrm{~V}$ primerjavi z Nemci so bili tudi prijaznejši in bolj zadržani do žensk, vendar se je ta zadržanost v vojni vihri spremenila v nasilje in je kar nekajkrat prišlo do posilstev na območju njihovega delovanja. ${ }^{94}$

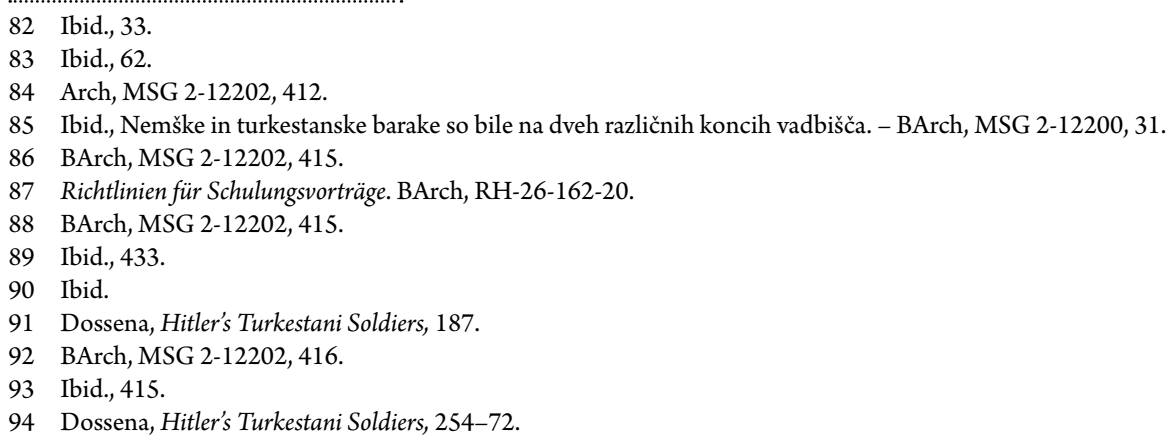


Tudi sporazumevanje ni bilo najlažje, saj so nemški vojaki znali le malo ruščine, uzbekistanščine ${ }^{95}$ (najbolj razširjenega turkestanskega jezika) pa praktično nič, medtem ko so se prostovoljci le počasi učili nemščino. Če so turkestanski pešaki nemščino še lahko vzeli z levo roko, so morali tisti, ki so delali na tehničnem področju, na primer pri vzdrževanju vozil, topov in streliva, poprijeti za nemške učbenike. »Tehnične sposobnosti Turkestancev sicer niso posebej velike, vendar ima ta primitivni narod velik interes za tehniko in podrobnosti. $\ll{ }^{96} \mathrm{Za}$ serviserje se je zahtevalo »široko « znanje nemškega jezika, saj bi lahko napačno razumevanje podrobnosti imelo katastrofalne posledice.

Tretja težava je bilo vprašanje enakopravnosti, ki je bila od vsega začetka ena ključnih nemških obljub, in Turkestanci so tudi pričakovali njeno izpolnitev. Resnica pa se je izkazala za popolnoma drugačno od propagande. Rekrute so najprej razdelili v bataljone, kjer je na enega Nemca prišlo približno 35 prostovoljcev. Ti bataljoni so bili glede oborožitve jasno zapostavljeni in tudi skoraj vse častniške položaje so zasedali Nemci. Nemškim vojakom se $\mathrm{v}$ začetku ni bilo treba preveč truditi razumeti Turkestancev, saj so jih imeli le za sredstvo zmanjševanja nemških žrtev. ${ }^{97}$ Nacisti so si želeli, da bi stvari v zvezi s turkestanskimi prostovoljci potekale nekako tako:

1. rekrutirati čim več turkestanskih ujetnikov, ki bi se bojevali namesto Nemcev in s tem preprečili nepotrebno prelivanje arijske krvi; ${ }^{98}$

2. po zmagi nad Sovjetsko zvezo ustanoviti neodvisno državo Turkestan, ki leži na drugi strani Urala, zato naj za Tretji rajh ne bi bil $\gg$ pomemben $\ll ; 99$

3. vrniti Turkestance $\mathrm{v}$ Turkestan, po možnosti kot voditelje novoustanovljene države, ki bi bila lojalna nacistični Nemčiji. ${ }^{100}$

Že konec leta 1942 je postalo jasno, da ne gre vse po načrtu. Porazi pri El Alameinu, Stalingradu in Kursku so prostovoljce vse bolj oddaljevali od domačega Turkestana, poleg tega pa so turkestanske enote, $v$ katerih je bilo le malo Nemcev, postajale vse bolj neobvladljive. Tako je z združitvijo turkestanskih in nemških vojakov, kot rečeno, nastala mešana 162. turkestanska divizija, ${ }^{101}$ kar je naciste prisililo, da so ponovno premislili svoj odnos do prostovoljcev. Kljub imenu je imela divizija nemško večino, zato je moral Wehrmacht poskrbeti za oborožitev, primerno za nemško vojsko. Še vedno niso bili popolnoma enakovredni nemški enoti, nemški poveljnik 13. čete 303. polka turkestanske divizije pa je, preden so jih poslali proti severni Italiji, povedal, da »bodo morali zapolniti najhujše vrzeli. Mi smo ponovno 'izgubljena čreda' znotraj nemške vojske. ${ }^{102}$ Nemci znotraj divizije so zaradi svojega sodelovanja $\mathrm{z} \gg$ ne-arijci $\ll$

95 Poveljnik 13. čete 303. polka se je uzbekistansko učil na lastno pest od prevajalca Turumbajeva. - BArch, MSG 2-12200, 36.

96 Ibid., 47.

97 Newland, Cossacks in the German army 1941-1945, 53.

98 BArch, MSG 2-12202, 147.

99 Burak, Germany and Turkestanis during the course of the World War II, 52.

100 BArch, MSG 2-12202, 410.

101 Po Seraphimu je divizija nastala iz nemških vojakov pomeranske divizije, ki je bila poražena pri sovjetskem Tveru. Moštvu, ki je ostalo, so dodali pripadniki armenske, gruzijske, azerbajdžanske in severnokavkaške legije. - BArch, MSG 2-12200, 3.

102 Ibid., 127. 
svojo enoto videli kot manjvredno drugim enotam Wehrmachta, medtem ko se je prostovoljcem zdelo, da niso enakovredni Nemcem znotraj turkestanske divizije. Turkestanec Muradjanov, ki je bil pred oblikovanjem 162. divizije ponosen, da lahko vodi četo, ${ }^{103}$ je tedaj, $\gg$ da ne bi bil nadrejen Nemcem $\ll,{ }^{104} \gg$ nazadoval $\ll$ v vlogo desetnika. ${ }^{105} \mathrm{~S}$ tem je dokončno postal $\gg$ komična figura, ki je nihče ni več jemal resno. $\ll{ }^{106}$

Najpomembnejše Seraphimovo spoznanje, ki daje podton vsem njegovim spominom, je dejstvo, da nacistična urjenje in propaganda nista veliko vplivala na prostovoljce. Ključen za uspešno integracijo v nemški Wehrmacht naj bi bil enakopraven odnos Nemcev do tujih tovarišev. ${ }^{107}$ Enake možnosti pri napredovanju, plači, oborožitvi, dolžini dopusta. ${ }^{108}$ Da vojaki obeh narodnosti niso nikoli postali enakopravni, sta kriva predvsem nacistično nezaupanje do Turkestancev in rasizem. Zaupanje v prostovoljce $^{109}$ je bilo stalnica $v$ pogovorih nemških častnikov. ${ }^{110}$ Ali bodo zbežali? Ali se bodo, ko bo trda predla, predali? Govoriti o dezerterstvu je nehvaležno, saj se ocene močno razlikujejo, včasih pa si popolnoma nasprotujejo. V začetni fazi, ko so se prostovoljci bojevali proti Sovjetski zvezi, naj bi bilo dezerterjev od 8 do 10 odstotkov vseh Turkestanov, medtem ko je leta 1945, ko je bila enota nastanjena v severni Italiji, delež padel na 2 do 3 odstotkov. ${ }^{111} \mathrm{Kljub}$ različnim odstotkom pa je dejstvo, da je bil vrhovni komisar OZAK, dr. Friedrich Rainer tako nezadovoljen s pobegi prostovoljcev v partizanske vrste, da je Heinrichu Himmlerju predlagal naj divizijo čim prej pošlje kam drugam. ${ }^{112}$

Poveljnik 13. čete 303. polka turkestanske divizije v svoji enoti skoraj ni imel pobegov, povedal je, da v njegovi enoti ni bilo dezerterjev, razen nekega mule, ${ }^{113} \mathrm{ki}$ po Seraphimovem mnenju $\gg$ nikoli ni postal pravi [nemški] vojak $\ll .{ }^{114}$ Nekega dne je ukradel blagajno, v katero so prostovoljci dajali prispevke za verske obrede, in iz Riminija, kjer je bila stacionirana divizija, »zbežal v San Marino in tam odprl gostilno $\ll .{ }^{115}$ Poleg nezaupanja je bil drugi temelj neenakosti nacistični rasizem, ki je pogojeval odnos do vsega, kar ni bilo germanskega izvora. Tega, da bi azijski Muradjanov poveljeval arijcem, ni bilo mogoče sprejeti, vendar pa so prostovoljce kljub temu spodbujali, naj se učijo nemškega jezika in vrednot. Zdi se, da v tem učenju ni bilo nobenih dolgoročnih ciljev,

103 Muradjanov v resnici ni vodil čete, vse odločitve znotraj čete je sprejemal njegov nemški svetovalec. - BArch, MSG 2-12200, 6. Podobno vlogo je v Operacijski coni Jadransko primorje imel Deutsche Berater, dodeljen prefektom šestih pokrajin

104 Ibid., 122.

105 Gefreiter.

106 BArch, MSG 2-12200, 122

107 BArch, MSG 2-12202, 476.

108 Pri dopustu prostovoljcev pride do vprašanja: Kam naj gredo? Nemški vojaki so odšli na dopust domov, kam pa naj bi se odpravili Turkestanci? - Ibid., 446.

109 Podobno nacisti niso zaupali slovenskim domobrancem, zaradi česar je prišlo do prisege. - Mlakar, Slovensko domobranstvo, 293.

110 BArch, MSG 2-12200, 135.

111 Drugi izračuni kažejo, da je med sovjetskim prostovoljci, ki so se borili za nemško stran, dezertiralo 1300 vojakov ali 1,5 odstotka. - Burak, Germany and Turkestanis during the Course of the World War II, 143.

112 Ferenc, Kapitulacija Italije in narodnoosvobodilna borba $v$ Sloveniji jeseni 1943, 554.

113 Islamski verski učitelj. V vsakem bataljonu je bil en mula. - BArch, MSG 2-12202, 484.

114 Ibid., 486.

115 Ibid., 448 . 
temveč le želja po čim lažjem sobivanju. Kljub temu pa je imela peščica prostovoljcev iluzijo o nečem večjem, da se skupaj z Nemci borijo za skupne vrednote. Nekateri prostovoljci so začeli »čutiti, da so ponosni nemški vojaki in Srednjeevropejci $\ll,{ }_{116}^{116}$ kar se je pokazalo, ko se je 303. turkestanski polk vračal iz bojev proti partizanom na Dolenjskem proti italijanskemu Tržiču. ${ }^{117}$ Ko so šli mimo neke vasi, se je turkestanski skrbnik konjev Polja obrnil proti avtorju spominov, s prstom pokazal na italijanske civiliste ter hvaležno dejal: »'Poglejte stotnik, kakšen nekulturen narod!'118 To je bil Turkestanec, ki je bil do takrat približno leto dni nemški vojak, na kar je bil izjemno ponosen, saj je videti kot polnopraven kamerad in Evropejec ter se počuti, da se tako tudi ravna z njim. $\ll^{119}$

\section{Zaključek}

Boj proti boljševizmu je bil pomemben motivacijski razlog, da so se kolaboracionisti pridružili nacistom. Mednje lahko štejemo tudi slovenske domobrance, katerih idejni vodja general Leon Rupnik je imel 23. junija 1944, na dan svetega Ahaca na radiu govor. Razlog za govor je bil spomin na bitko pri Sisku (22. junija 1593). Zmaga kranjskih in štajerskih »vojakov nad Turki in obvarovanje krščanskega sveta pred prodirajočimi hordami z Vzhoda je bila hvaležna tema za primerjavo $s$ tedanjim položajem. Slovenci so bili tedaj in tudi zdaj (domobranci!) skupaj z nemškimi vojskovodji del mnogonarodne vojske, ki je na koncu zmagala. $\ll{ }^{120}$ Predsednik Ljubljanske pokrajine pa je pozabil omeniti, da so bili natanko 350 let po zmagi nad osmanskimi Turki prav muslimanski vojaki, ki so govorili Turkom podoben jezik, tisti, ki so prispevali svoj delež k nacistični zasedbi Ljubljanske pokrajine in širše OZAK.

Ironično je torej, da ni bil samo partizanski boljševizem tisti, ki je »pripeljal vzhodnjaštvo « na območje severnega Jadrana (t.i. horde $\mathrm{z}$ Vzhoda), kakor je trdila protikomunistična propaganda. To so $\mathrm{v}$ resnici storili že nacisti sami, ko so na to območje pripeljali Turkestance. Ti so do mobilizacije v kolaboracionistične enote živeli v obupnih življenjskih razmerah $\mathrm{v}$ zbirnih taboriščih za sovjetske ujetnike in so bili veseli, ko so jim nacisti dali možnost preživetja v zameno za boj na njihovi strani. Šli so čez proces rekrutacije, v katerem so nacisti imeli najraje prostovoljce, ki so imeli kar največ zamer proti sovjetski oblasti, ter tiste, ki so vsaj malo govorili nemško. Nacisti so rekrute želeli naučiti nemškega reda in discipline ter jih s pomočjo propagande prepričati, da se bojujejo za Tretji rajh. Poveljniki, na čelu z Oskarjem von Niedermayerjem, pa niso računali na človeško plat prostovoljcev, ki so veliko bolj kot propagando čutili rasizem in poglede z viška nemškega moštva. Zaradi takšnih razlogov so se dogajali pobegi Turkestancev kot je primer Mehdija Huseynzadeja - Mihajla iz 314. azerbajdžanskega

116 Ibid., 482.

117 BArch, N 122-6.

$118 \gg$ Bot kapetan, kakoj beskulturnij narod! $\ll$ BArch, MSG 2-12200, 285.

119 BArch, MSG 2-12202, 484.

120 Mlakar, Slovensko domobranstvo, 246. 
polka, ki je pobegnil k slovenskim partizanom. ${ }^{121} 2$. aprila 1944, le nekaj tednov preden so se njuni nekdanji kameradi iz turkestanske divizije umaknili iz OZAK, je skupaj s še enim prebežnikom v kinu na Opčinah nastavil bombo, ki je ubila sedem nemških vojakov. Čez tri tedne je ponovno eksplodiralo, tokrat v Deutsches Soldatenheim na tržaški ulici Ghega, kjer je bilo ubitih pet Nemcev. ${ }^{122}$ Neprimerna integracija kolaboracionistov $\mathrm{v}$ nemški Wehrmacht je imela $\mathrm{v}$ tem primeru uničujoče posledice.

\section{Viri in literatura}

\section{Arhivski viri}

- BArch, Bundesarchiv Militärarchiv Freiburg:

- MSG 2-12200 Seraphim, Hans Günther Dr. (Stabsoffizier der armenischen Legion / 162. Infanterie-Division (turkmenische) 1939-1944 geboren 21. 1. 1903, gestorben 13. 2. 1992 Bd. 4: Kriegserinnerungen. - Infanterie-Regiment 303 der Turk-Division (1943-1944) 1950.

- MSG 2-12202 Bd. 6: Kriegserinnerungen (1943-1945) 1950.

- N 122-6 Nachlaß von Niedermayer.

- PERS 6-1679 Niedermayer, Oskar Ritter von, Prof. Dr., geb. 8. 11. 1885 Kommandeur d. Osttruppen z.b.V. 703 b. Oberbefh. West.

- RH 26-162-20 Dolmetscherwesen; Betreuung der Turkestanischen Legionäre 9. Mai-19. Juni 1943.

- PAAA, Politisches Archiv des Auswärtigen Amts:

- Pol XIII-R 105186 Lage der russischen Emigration in Italien.

\section{Literatura}

- Bougarel, Xavier, Raphaëlle Branche in Cloé Drieu, ur. Combatants of Muslim Origin in European Armies in the Twentieth Century: Far From Jihad. London: Bloomsbury Publishing Plc, 2017.

- Böhler, Jochen in Robert Gerwarth, ur. The Waffen-SS: A European History. Oxford: Oxford University Press, 2017.

- Burak Sakal, Halil. Germany and Turkestanis During the Course of the World War II (1941-1945). Ankara: [H. Burak Sakal], 2010.

- Carnier, Pier Arrigo. L' armata cosacca in Italia: 1944-1945. Milano: Mursia, 1993.

- Collotti, Enzo. Il Litorale Adriatico nel Nuovo ordine. Milano: Vangelista editore, 1975.

- Dossena, Paolo. Hitler's Turkestani Soldiers: A History of the 162nd (Turkistan) Infantry Division. Solihull: Helion \& Company, 2015.

- Ferenc, Tone. Kapitulacija Italije in narodnoosvobodilna borba v Sloveniji jeseni 1943. Maribor: Obzorja, 1967.

- Gortani, Michele. Il martirio della Carnia dal 14 marzo 1944 al 6 maggio 1945. Tolmeč: Grafico "Carnia”, 1966.

- Hostler, W. Charles. »The Turks and Soviet Central Asia.« Middle East Journal, št. 3 (1958): 26169.

121 Rossi, Soldati dell'armata rossa al confine orientale, 225.

122 Giorgio Liuzzi, Violenza e repressione nazista nel Litorale Adriatico (Trst: Istituto regionale per la storia del movimento di liberazione nel Friuli Venezia Giulia, 2014), 222. 
- Hughes, L. Thomas. »The German Mission to Afganistan. 1915-1916.« German Studies Review, št. 3 (2002): 447-76.

- Jones, W. Jeffrey, »'Every Family Has Its Freak': Perceptions of Collaboration in Occupied Soviet Russia, 1943-1948.« Slavic Review, št. 4 (2005): 747-70.

- Judt, Tony. Povojna Evropa 1945-2005. Ljubljana: Mladinska knjiga, 2007.

- Liuzzi, Giorgio. Violenza e repressione nazista nel Litorale Adriatico: 1943-1945. Trst: Istituto regionale per la storia del movimento di liberazione nel Friuli Venezia Giulia, 2014.

- Mlakar, Boris. Slovensko domobranstvo: 1943-1945: ustanovitev, organizacija, idejno ozadje. Ljubljana: Slovenska matica, 2003.

- Mortadel, David. »Islam and Germany's War in the Soviet Borderland. 1941-1945.« Journal of Contemporary History, št. 4 (2013): 784-820.

- Newland J., Samuel. Cossacks in the German Army 1941-1945. Abingdon: Routledge, 2002.

- Penter, Tanja. »Collaboration on Trial: New Source Material on Soviet Postwar Trials against Collaborators. « Slavic Review, št. 4 (2005): 782-90.

- Penter, Tanja. »Local Collaborators on Trial: Soviet War Crimes Trials under Stalin (19431953).« Cahiers du Monde russe, št 2/3 (2008): 341-64.

- Pil'ko, Nadežda Sergeevna. Slovenija v gody okkupacii: 1941-1945 gg. Sankt Peterburg: Aletejja, 2009.

- Rossi, Marina. Soldati dell'armata rossa al confine orientale, 1941-1945 con il diario inedito di Grigorij Žiljaev. Gorizia: LEG, 2014.

- Seidt, Hans-Ulrich. »From Palestine to the Caucasus-Oskar Niedermayer and Germany's Middle Eastern Strategy in 1918.« German Studies Review, št. 1 (2001): 1-18.

- Verardo, Fabio. I cosacchi di Krasnov in Carnia. Udine: Aviani e Aviani, 2010.

- Verardo, Fabio. »Offesa all'onore della donna «: le violenze sessuali durante l'occupazione cosacco-caucasica della Carnia 1944-1945. Trst: Istituto regionale per la storia del movimento di liberazione nel Friuli Venezia Giulia, 2016.

- Zeidler, Manfred. »Das 'kaukasische Experiment'. Gab es eine Weisung Hitlers zur deutschen Besatzungspolitik im Kaukasus?.«Vierteljahrshefte für Zeitgeschichte, št. 3 (2005): 475-500.

- Zupanc, Ciril. Mihajlo, obveščevalec in diverzant IX. korpusa. Nova Gorica: Goriški muzej, 2007.

\section{Denis Cerkvenik}

\section{NAZI RECRUITMENT AND TRAINING OF SOVIET PRISONERS OF WAR ON THE EXAMPLE OF THE $162^{\text {nd }}$ TURKESTAN DIVISION (1942-43)}

\section{SUMMARY}

The fight against Bolshevism was an important reason and motiv for collaborationists to join the Nazi side. Collaborationist formations also included the Slovene Home Guard, whose ideological leader General Leon Rupnik held a radio speech on St. Ahac's Day, on 23 June 1944. The reason for it was the anniversary of the battle of Sisak (22 June 1593). The victory of the Carniolan and Styrian "soldiers against the Turks and the protection of the Christian world from the invading hordes from the East was a convenient subject for comparison with the situation at that time. Then and 
now, Slovenians (the Slovene Home Guard!), together with the German military leaders represented a part of a multi-ethnic army that eventually won." ${ }^{223}$ The President of the Ljubljana Province forgot to mention that exactly 350 years after the victory over the Ottoman Turks, it was also the Turkestani soldiers that contributed to the Nazi occupation of the Ljubljana Province and the wider Operational Zone of the Adriatic Littoral.

What is ironic is that the Partisan Bolshevism was not the only movement that "brought Orientalism" to the area of the northern Adriatic (the so-called hordes from the East), as the anti-communist propaganda claimed. This had, in fact, already been done by the Nazis themselves when they had brought the Turkestani collaborationists to the area. Before their mobilisation into the collaborationist units, these men had endured desperate living conditions in the concentration camps for Soviet prisoners. Therefore, they were glad when the Nazis offered them a chance to survive in exchange for fighting for the Nazi side. They went through a recruitment process, during which the Nazis preferred volunteers who spoke at least a little German and those who held as much resentment as possible against the Soviet government. The Nazis wanted to instil the German order and discipline in the recruits and used propaganda to convince them to fight for the Third Reich. Despite the propaganda that the Nazi commanders were trying to convince these men of during training, the Turkestani volunteers had to contend with the racism of the German soldiers. This was one of the main reasons why many Turkestani soldiers escaped, for example in the case of Mehdi Huseynzade - Mihajlo from the $314^{\text {th }}$ Azerbaijani Regiment, who fled to join the Slovenian Partisans. ${ }^{124}$ On 2 April 1944, just weeks before his former comrades from the Turkestani Division withdrew from the Operational Zone of the Adriatic Littoral, he and another Turkestani Partisan had set off a bomb at a cinema in Opčine, killing seven German soldiers. Three weeks later, another bomb exploded again, this time in the Deutsches Soldatenheim on Ghega Street in Trieste, where five Germans were killed. ${ }^{125}$ In this case the inappropriate integration of collaborators into the German Wehrmacht had devastating consequences.

123 Mlakar, Slovensko domobranstvo, 246.

124 Rossi, Soldati dell'armata rossa al confine orientale, 225.

125 Liuzzi, Violenza e repressione nazista nel Litorale Adriatico, 222. 